\title{
Food security for Africa: an urgent global challenge
}

\author{
Albert Sasson
}

\begin{abstract}
In 2012, food insecurity is still a major global concern as 1 billion people are suffering from starvation, under-, and malnutrition, and the Food and Agriculture Organization of the United Nations (FAO) has concluded that we are still far from reaching millennium development goal (MDG) number 1: to halve extreme poverty and hunger by 2015. In sub-Saharan Africa, the number of people suffering from hunger is estimated at 239 million, and this figure could increase in the near future.

There are many examples of food insecurity in sub-Saharan Africa, some of them having reached catastrophic dimensions, for example, in the Horn of Africa or southern Madagascar. Food insecurity is not just about insufficient food production, availability, and intake, it is also about the poor quality or nutritional value of the food. The detrimental situation of women and children is particularly serious, as well as the situation among female teenagers, who receive less food than their male counterparts in the same households.

Soaring food prices and food riots are among the many symptoms of the prevailing food crisis and insecurity. Climate change and weather vagaries, present and forecast, are generally compounding food insecurity and drastically changing farming activities, as diagnosed by the Consultative Group on International Agricultural Research (CGIAR) in June 2011.

The key cause of food insecurity is inadequate food production. Since the global food crisis of 2007-2008, there has been an increasing awareness throughout the world that we must produce more and better food; and we should not be derailed from this goal, despite some relief brought by the good cereal harvests in 2011-2012. This is particularly true in sub-Saharan Africa, which needs and wants to make its own green revolution.

The African challenge indeed is key to mitigating food insecurity in the world. Commitments were made by the heads of states and governments of the African Union to double the part of their domestic budgets devoted to agriculture in 2010-2011, so as to reach 10\%. Technical solutions exist and there are indeed, throughout Africa, good examples of higher-yielding and sustainable agriculture. But good practices have to spread throughout the continent, while at the same time social and economic measures, as well as political will, are indispensable ingredients of Africa's green revolution. It is also necessary that international donors fulfil their commitment to help African farmers and rural communities and protect them against unfair trade, competition, and dumping of cheap agrifood products from overseas.
\end{abstract}

Keywords: Millennium development oals (MDGs), food insecurity, food quality, food riots, volatility of food prices, climate change, inadequate food supply, green revolution, Alliance for a Green Revolution in Africa (AGRA), fair trade, trade barriers, African farmers

\section{Hunger: A global shame}

Far from reaching millennium development goal number 1: to halve extreme poverty and hunger by 2015

On September 14, 2010, the Food and Agriculture Organization of the United Nations (FAO) published its estimates concerning the number of people suffering

Correspondence: pralbert.sasson@gmail.com

Hassan II Academy of Science and Technology (Rabat, Morocco),

Bio-Euro-Latina (Paris, Madrid), Former Assistant Director-General of UNESCO (Paris), 51 Rue d'Alleray, Paris, 75015, France from hunger in 2010: 925 million. This figure was below the 1,020 billion in 2009 , but it was higher than the number reached before the 2008 global food crisis. The 2010 figure corresponded to $13.5 \%$ of the world population, while the 2015 objective (millennium development goal (MDG) number 1) was $8 \%$. The FAO concluded that we were still far from achieving MDG 1, that is, halving the number of hungry people worldwide by 2015 [1].

In 2010, the regional distribution of people suffering from hunger was the following: 578 million in the Asia 
Pacific region; 239 million in sub-Saharan Africa; 53 million in Latin America and the Caribbean; 37 million in North Africa; and 19 million in developed countries [1].

These figures were expected to increase due to another global food crisis in 2011, spurred by an important rise in commodity and food prices. According to the World Bank, another 44 million people living on less than US $\$ 1.25$ per day had fallen into extreme poverty between June and December 2010 because of the increase in food prices. Consequently, by early 2011, 1.2 billion people were in that situation. And on February 4, 2011, the FAO's Director-General, Jacques Diouf, and the French agriculture minister, Bruno Le Maire, warned during a press conference against 'a real risk of a global food crisis'. The FAO's Director-General stressed that 'not only was there a risk, but food riots had already occurred in some regions of the world because of food price increases and governments had found themselves in a difficult situation, alluding to Tunisia and Egypt. The FAO's monthly index of global food prices, which was published on the eve of the press conference, had reached another historical peak ([2]; see also [3]).

Olivier de Schutter, special rapporteur of the United Nations on the right to food, stated: 'If most poor countries are still very vulnerable, it is because their food security depends too much on food imports whose prices are increasingly high and volatile'. Since the 2008 food crisis, it is indeed true that volatility of food prices has become an important feature of the global situation. That is why, according to Olivier de Schutter, the international community should respond rapidly 'by adopting regulation measures and by designing a global governance of commodity and food stocks, based on a more transparent management of the stocks every country keeps'. This crucial issue of market stability was the focus of a meeting organized by the FAO on 24. September 2010. The regulation of the markets of agricultural commodities was also a key subject of the G20 meeting organized by France in Paris in February 2011 [1].

Unfortunately, more action is needed rather than general statements, and international cooperation and solidarity must prevail over selfish national interests if we really want to eradicate such a global shame as the starvation and undernutrition of billions of people. For instance, the pledges made in L'Aquila (Italy) in 2008 are far from becoming a reality. During that G8 meeting, heads of states and governments made the commitment to gather US $\$ 22$ billion ( $€ 16.8$ billion) over 3 years in order to struggle against food insecurity. Also at that time, all the countries present stressed the need to increase the proportion of agriculture-oriented investments in public aid for development, which fell from $17 \%$ in 1980 down to $3.8 \%$ in 2006, and thereafter rose to around 5\%. All of these commitments are far from becoming a reality. A US\$900 million 'global program for food security' was announced only on April 22, 2010. It is funded by the United States, Canada, Spain, and South Korea, and the Bill and Melinda Gates Foundation also joined the program. On June 23, 2010, an amount of US $\$ 224$ million was allocated to the first five beneficiaries: Bangladesh, Haiti, Rwanda, Sierra Leone, and Togo [1].

The Bill and Melinda Gates Foundation is bringing its expertise more than funds (US\$30 million). As stressed by Bill Gates, the Foundation has accumulated unique experience while disbursing US\$1.5 billion over 4 years (2006-2009) for activities aimed at improving food security. This area of action has become, according to Bill Gates, the other global priority urgency, 'just after health'. He added that the solution was to assist small farmers 'to increase their productivity, to find outlets and to adopt new agricultural techniques'. Bill Gates is convinced that food security is more complex than aid to healthcare, because in that case, one needs the cooperation of local governments. Food insecurity often prevails where public infrastructures are corrupted and very backward. Bill Gates recognized that the endeavour is huge: out of the 1 billion people who live with US\$1 or even less per day, 75\% are in rural areas; and the US\$900 million devoted to the 'global program for food security' represent the equivalent of 1 or 2 days of subsistence for every person among the extremely poor [4].

In sub-Saharan Africa, food insecurity is a major concern, as shown by the following very disturbing examples.

\section{Food insecurity in sub-Saharan Africa: Examples Madagascar}

Under the threat of starvation, the populations living in the deep south of Madagascar (Malagasy) are adopting survival strategies, such as eating seeds to be sown for the following harvests and therefore reducing the likelihood of any meaningful crops. In this remote part of the country, which has been neglected by public authorities as well as by development institutions and that has been hit by a severe drought since 2008, some 720,000 inhabitants (about $40 \%$ of the population of the three regions of Atsimo-Andrefana, Androy, and Anosy) were suffering from starvation, according to the World Food Programme (WFP). The number of districts classified as 'in food difficulty' rose to 53 in 2010, compared with 31 in 2008 and 45 in 2009. 'Even those districts which were considered granaries are now hit by food insecurity', as stressed by the representative of the WFP in Madagascar, Krystyna Bednarska [5].

In 2010, and for the second year in sequence, rainfall was below $350 \mathrm{~mm}$, and the rainy period that generally starts at the beginning of November had not yet started by the end of December. In 2009 and 2010, 80\% of the maize harvest had been destroyed. In addition, the 
provision of drinking water was even more difficult because rivers were dry. In the region of Androy, only 7\% of the population had access to drinking water [5].

Food prices rose: they were $50 \%$ higher in the south of Madagascar than in the rest of the country. Households were selling their livestock, considered as their asset, but which had no value in the case of extreme drought. Leaving behind women and children, men were migrating to the north of the country, where they hoped to earn more money. In April 2011, at the peak of the intercrop season, it was forecast that some 6,700 children would suffer from severe malnutrition and would eventually die, according to the United Nations Children's Fund's (UNICEF) representative, Bruno Maes [5].

While the risks of severe malnutrition were increasing in that region, the number of cases of tuberculosis was rising, as well as women's mortality during delivery, and the healthcare system was becoming increasingly ineffective. The vaccination rate was $41 \%$ in the south of the country, compared with $88 \%$ (average) in the rest of the country. Bruno Maes stated that ' $87 \%$ of health centers were lacking basic medicines and $55 \%$ had no fuel to operate their refrigerators' [5]. The non-governmental association Médecins sans Frontières (Medical Doctors without Frontiers), which had left the country in 2005 after 18 years of presence, decided to bring back a permanent team because of the gravity of the health situation. The various donors could not cope with such a desperate situation. The WFP, which wished to raise the number of receivers of urgent assistance from 80,000 to 200,000, was seeking funds. Of the 90 health centers, 52 that UNICEF had supported over 18 months in the south of the country could close down by the end of 2010 because of lack of funds [5].

\section{The Horn of Africa}

Around 12 million people were suffering from starvation in the Horn of Africa (Somalia, Ethiopia, northeastern Kenya), stricken by the worst drought in the past 60 years, announced the FAO on July 12, 2011. A few days before, the WFP had estimated that, in this region, 10 million people needed food assistance. The SecretaryGeneral of the United Nations called an emergency meeting with all directors of the United Nations agencies and requested member states for a more generous attitude regarding their help to the countries suffering from starvation. In fact, less than half of the US\$1.6 million ( $€ 1.14$ billion) needed for the assistance programme to be carried out in that region had been collected.

In northeastern Kenya, around Wajir, capital of that province, near the border with Ethiopia and Somalia, drought has been particularly severe. Trucks filled with water were brought there once a week from a neighbouring community in order to meet minimum needs for drinking water. Fifty kilometres from Wajir, in the city of Griftu, rainfall volume has been about $60 \%$ to $70 \%$ lower than the average for 1.5 years. While in October 2010, 50 children had been treated due to malnutrition, this increased to 700 in July 2011 [6].

Drought is not exceptional in the Horn of Africa, but 2011 was different: recurrent droughts were more frequent since the 2009 episode and plant regrowth was almost impossible. Nomadic cattle herders had to seek for farther pastures, sometimes several hundred kilometers away. They often left their families behind them without any resources. For other livestock herders, it was already too late: animals died from starvation, and their owners tried to sell them at a very low price before death occurred [6].

Another consequence of the very severe drought was the spike in food prices. In Wajir, the price of rice (the staple food of the local population) rose from 60 to 80 shillings $(€ 0.64)$ per kilogram in 3 months, while the price of sugar doubled. The purchasing power of people has almost become nil [6].

Development associations stated that they had warned local authorities since June 2010 about the risk of a major reduction in rainfall. They said that nothing had been done, thinking that the situation would improve. Many were those who underlined the lack of investment and long-term planning by the Kenyan government for the northeast of the country. They had, nevertheless, solutions in mind: limitation of the installation of sedentary people on land traditionally used by herders; convince livestock herders to sell their animals earlier, to reduce the size of their herds and flocks so as to make them more economically viable; and advocate for a diversification of their activities. But the central government seemed to focus on short-term solutions [6].

Although not as dramatic as in northeastern Kenya, the lack of rainfall or much scarcer rains have affected the region southeast of Nairobi. Maize harvests have been drastically reduced and about 400 farmers have grown cassava instead of the usual crop; they were to reap their first harvest in 2011. Cassava needs less water than maize, as well as fewer pesticides. In order to avoid poisoning by cyanide (in the tubers), selected harmless varieties are distributed to farmers by the Kenya Agricultural Research Institute (KARI); the project is funded by the European Union. Another group of 560 farmers in the village of Mbuvo, south of Nairobi, were harvesting their first crop of cassava by the end of July 2011. They formed a cooperative in charge of collecting, weighing, washing, and peeling the tubers of cassava, before transforming them into a white powder that is dried on large wooden mats. The derived products are cassava flour, chips, animal feed, and meals made with cassava leaves. The cooperative's objective was to cultivate 300 hectares 
in 2012 thanks to the use of machinery, and later on, to export the products to southern Sudan, Germany, and the United Kingdom [7].

In addition to cassava, KARI has been supporting the cultivation of another traditional crop, sorghum, which is also tolerant to drought. In 2011, about 3,000 farmers were selling their production to local brewers. Food security has become a top priority and KARI's research and extension work aimed at finding appropriate solutions in close collaboration with the farmers, particularly those working in a drought-prone environment.

On July 20, 2011, 'The United Nations declared that famine existed in two regions of southern Somalia: southern Bakool and Lower Shabelle', as stated by the United Nations Office for the Coordination of Humanitarian Affairs for Somalia. Both areas are controlled by Shebab insurgents. Famine is declared when over 30\% of children suffer acute malnutrition, the mortality rate reaches two adults or four children per day per 10,000 people and the population has access to much less than 2,100 kcal of food per day. 'Across Somalia, nearly half of the population, 3.7 million people, were in crisis, of whom an estimated 2.8 million people were in the south, the United Nations' statement read. 'Consecutive droughts have affected the country in the last few years, while the ongoing conflict has made it extremely difficult for agencies to operate and access communities in the south of the country', it added.

The relief agency Oxfam has been urging donors to provide the US\$800 million desperately needed to help 10 million hungry people in the Horn of Africa. Of the estimated US\$1billion needed to stave off a major humanitarian catastrophe, Oxfam stated that only around US\$200 million in new money had so far been provided. Over the 2 weeks before the United Nations' statement, the United Kingdom had pledged an estimated US\$145 million (almost 15\% of what was needed), the European Union around US\$8 million, Spain nearly US\$10 million, and Germany around US\$8.5 million.

United Nations' officials warned that unless urgent action were taken, the areas afflicted by famine would expand, that is to all eight regions of southern Somalia, within 2 months, due to poor harvests and infectious disease outbreaks. Famine implied that at least 20\% of households faced extreme food shortages, with limited ability to cope. Malnutrition rates in Somalia were the highest in the world, with peaks of $50 \%$ in certain areas of southern Somalia. Consequently, 'every day of delay in assistance was literally a matter of life and death for children and their families in the famine-affected areas, said Mark Bowden, the United Nations humanitarian coordinator for Somalia.

Thousands of Somalis have fled to seek refuge in neighbouring Ethiopia and Kenya. In the latter country, they were streaming into overcrowded camps hosting some 380,000 people, more than four times their original capacity. On July 19, 2011, the United Nations refugee agency stated that death rates among refugees arriving in Ethiopia's Dolo Ado area had reached 7.4 deaths per 10,000 in June 2011, 15 times more than the baseline rate in sub-Saharan Africa.

Soaring world food prices had made matters worse. In Somalia, the cost of sorghum, the local staple, had risen $240 \%$ since October 2010. In Kenya, the price of maize had tripled. Food hoarding had been reportedly aggravating shortages, even when rain had been plentiful. Parts of Kenya had a bumper harvest, leaving non-governmental organizations (NGOs) to wonder why the government's strategic grain reserves were so low. An estimated 3.5 million Kenyans were in urgent need of food. So were 533,000 refugees in the overcrowded Dadaab camp near the border with Somalia (as of July 14, 2011).

Who is to blame? An oscillation in the climate in the form of La Niña, a cooling of the surface temperatures across the equatorial eastern-central Pacific, causing big changes in airflow and weather patterns, is likely to have contributed to the droughts. But Jane Cocking, Oxfam's humanitarian director, stated that 'this is a preventable disaster and solutions are possible'. The worst-affected areas were also the poorest in the region. Long-term investment could have made villages and towns more resilient.

\section{Food quality and gender inequality}

In sub-Saharan Africa (and South Asia), a high proportion of female teenagers aged between 15 and 19 years are suffering from anaemia (the highest rate of $68 \%$ is registered in Mali) and weight insufficiency $(47 \%$ in India), while male teenagers of the same age are suffering less from these ailments. This is one of the numerous disparities between the sexes revealed by UNICEF, published on February 25, 2011 and devoted to teenagers [8].

To elucidate the reasons for these disparities in the area of nutrition, an international group of researchers and nutritionists has decided to study the eating habits of more than 2,000 teenagers aged between 13 and 17 years in the south of Ethiopia, and this independently from UNICEF. Ethiopia is one of the poorest countries in the world, where more than $50 \%$ of the population was less than 18 years old in 2009 and where $85 \%$ of teenagers were living in rural areas. Over 5 years, Tefera Belachew (University of Jimma, Ethiopia) and colleagues have interviewed families about their food habits and their health. Their study, published in January 2011, has shown that the health of boys and girls was similar in normal situations, but differed when access to healthy food becomes difficult [8]. 
Among the teenagers interviewed, about 25\% of the females have been confronted with food insecurity, compared with $16 \%$ of the males. As a direct consequence, girls suffer more from general weakness and pathologies. Boys were generally fed first and received food of better quality. Pietr Van Dooren of the Institute of Tropical Medicine in Antwerp, Belgium, stated that in an Ethiopian family, the boy is often perceived as having a more important economic and religious role to play; people tend to believe that he will be more productive and more able to manage the household in case of crisis'. Roland Kupka, a nutritionist working for UNICEF in West Africa, also stated: 'In a context of food insecurity, the social status of women raises many problems. Men should receive the best food, while women eat leftovers, and generally food of lesser quality'. These statements underline the detrimental situation of women who play a key role in the country's economy, especially in rural areas: $45 \%$ of Ethiopia's workers who cultivate land are women [8].

\section{Impact of soaring food prices}

In 2007-2008, rocketing food prices were the most obvious symptoms of the global food crisis. They have sparked riots in many countries, which, according to an executive of an important international body attending the World Economic Forum (2008) in Davos, Switzerland, generated more concern among governments than the rise in oil and petrol prices.

At the beginning of 2011, world food prices had risen above the peak they reached in 2008, driven by rising demand in developing countries and weather vagaries, including drought in Russia and Ukraine, and a dry spell in North China. That was a time when hundreds of millions of people fell into poverty, food riots were shaking governments in many developing countries, exporters were banning grain sales abroad, and agricultural lands were purchased or rented by rich grain-importing nations in poor agricultural ones [9].

This time, too, there have been export bans, food riots, panic buying, and emergency price controls, just as in 2007-2008. Fears that drought might cause havoc in the wheat harvest in China, the world's largest, have been sending shock waves through world markets. Anger over rising bread prices has played a part in the popular uprising throughout the Middle East. There are differences between the two periods, but the fact that agriculture has experienced two big price spikes in less than 4 years suggests that something serious is rattling the global food chain [9].

The World Bank has stated that the spike in food prices had pushed 44 million people into extreme poverty since June 2010. The FAO warned that Mozambique, Uganda, Mali, Niger, and Somalia were extremely vulnerable to instability because of rising prices, along with Kyrgyzstan and Tajikistan in Asia, and Haiti, Guatemala, Bolivia, and Honduras in Latin America. Misguided government policies could make matters worse, such as stockpiling of food by some countries, or agricultural export bans, which discourage investment in production.

\section{Food riots}

In West Africa, in Burkina Faso (Bobo-Dioulasso), on February 20, 2008, rioters who protested against a $65 \%$ rise in the price of some foodstuffs in January burnt government buildings and looted stores. Days later, in Cameroon, a taxi drivers' strike over fuel prices became a massive protest against soaring food prices, leaving around 20 people dead, while hundreds were arrested. In Senegal, in March 2008, police in riot gear used tear gas and beat people protesting against high food prices and later raided a television station that broadcast images of the event $[10,11]$.

In Cairo, the military was put to work baking bread as bread lines at bakeries that distribute state-subsidized bread became the scene of fights. The government feared that these fights could become the spark that ignited wider anger at a repressive government. In Yemen, food riots turned deadly, taking at least a dozen lives [10,12].

In Morocco, while trade unions warned against the degradation of consumers' purchasing power and its implications for social peace, and a newspaper requested the authorities to ensure that food prices would not exceed some 'red lines', people took to the streets at the end of September 2007 and clashed with the police in the city of Sefrou, located in the center of the country. Some 50 people were wounded and dozens of food rioters were arrested. In order to prevent a country-wide massive protest, the increase in bread price was cancelled and the state had to bear the brunt of the $25 \%$ rise in the price of a loaf of bread (1.50 dirhams, or $€ 0.14)$. Further to a poor cereal harvest in 2006-2007 due to a severe drought during the spring (instead of the 90 million quintals harvested in 2005-2006, only 20 million quintals were harvested in 2006-2007), Morocco had to import large quantities of soft wheat [13].

A striking example of food riots and popular uprisings due to the increase in food prices is that of Mozambique. In Maputo, the capital, and other cities of this southern African country, on September 1, 2010, people took to the streets after the government announced a $25 \%$ to $30 \%$ increase in the price of bread for the following week. Shops and banks were looted, cars stoned, and roads barricaded with rocks and burning tyres during 3 days of rioting that paralyzed the capital and shut down the main airport. The riots left at least a dozen dead and more than 400 injured. Police said they had to resort to live ammunition against protesters after running out of rubber bullets. Nearly 300 demonstrators 
were arrested, including nine accused of 'incitement' for sending out mobile-phone text-messages urging people to join the protests against rising utility, transport, and food prices [14].

After having declared that the increase in bread price was 'irreversible' during an extraordinary meeting, the government called off the increase and apologized, saying it had never authorized the use of lethal force. In 2008, food riots occurred in Cameroon and Somalia, and spread through Mozambique. Inflation was endangering the life of the poorest sections of the country's population and was also exacerbating the discontent of people against the governments. The increase in the price of bread was not the only reason for rioting: the price of water rose $12 \%$ and that of electricity $13 \%$ just before the food riots, and a few months before the events the price of bread had been increased in a similar way. Finally, the government and trade unions had signed an agreement to raise by $50 \%$ the fare of collective minibuses [15].

Despite receiving billions of dollars in international aid since the end of its civil war in 1992 and having one of the world's fastest-growing economies, Mozambique remains poor and unequal. Most of its 20 million people live on less than $\$ 1.25$ a day. There is almost no state welfare. The smallest rise in the cost of living can become a question of life and death. Although the government has blamed the rise in the cost of bread on soaring global wheat prices, that was not the main factor. It had more to do with a sharp fall in the metical, Mozambique's currency ( $-43 \%$ compared with South Africa's rand, between January and September 2010), coupled with a poor harvest in the south of the country in 2010 due to drought. Despite vast swathes of potential farmland, only a small proportion is developed, as the country relies on imported food, mostly from its neighbour, South Africa [14].

All of these events occurred when Mozambique was welcoming investors interested in exploiting the country's vast natural resources. For instance, according to Noticias, a newspaper close to the government, China intended to invest US $\$ 13$ billion in the country. With an economic growth of about 7\% in 2010, Mozambique seemed to be making good progress towards recovery from a civil war that led to about 1 million deaths between 1976 and 1992. There were, however, serious accusations of corruption at the top of the state. Some of its decisions also seemed difficult to understand: for instance, contracts were signed to extend the areas to be cultivated with jatropha (in order to produce biodiesel from its oil) while the country had serious problems of food supply [15].

The government announced an 'action plan' to cancel the rise in utility tariffs for the poorest, to reduce the price of rice and sugar, in addition to cancelling the $30 \%$ rise in bread prices forthwith. It has also promised to freeze the salaries of politicians and senior civil servants. The latest measures were to remain in force until the end of 2010. By then, the government was expected to issue a longer-term plan for economic and social stability [14].

\section{Impact of climate change}

Climate change and global warming are considered major threats to agriculture and food production. In 2007, the United Nations predicted that 'zones struck by drought in sub-Saharan Africa might increase from 60 million to 90 million hectares from now to 2060 ...' and that 'the number of people suffering from malnutrition might increase up to 600 million from now to 2080'. On 1 February 2008, the journal Science published forecasts of Stanford University, California, which predicted that South Africa could lose more than $30 \%$ of its maize production from now to 2030 [16].

Catastrophic floods and severe droughts are inflicting heavy damage to sub-Saharan Africa's ecosystems and agroecosystems, threatening the lives of tens of millions of people. For instance, on August 25, 2008, the United Nations' humanitarian coordination in Chad announced that about 30,000 persons had been affected by floods in the south of the country. In Ethiopia, according to the Red Cross, 75,000 persons were severely hit by drought. It is not easy to correlate these events with climate change, but they enable the experts to forecast the dangers and threats of climate change in Africa, which produces only $5 \%$ of the world's emissions of greenhouseeffect gases [17].

Amidst the debates on climate change, Africa is 'the forgotten continent', as stated by Yvo Boer, SecretaryGeneral of the United Nations Convention on Climate Change, in Accra (Ghana), during an international conference on the follow-up to the Kyoto Protocol, which ended on August 27, 2008. According to Ghana's president, John Kufuor, Africa was already suffering from 'climate shocks': in his country, rainfall has decreased by $20 \%$ over the past 30 years. This rainfall decrease has been confirmed, on a greater scale, by German and African scientists during a symposium held in Ouagadougou (Burkina Faso) on August 26, 2008: the rainfall season in West Africa starts 30 days later than 40 years ago. According to the research programme Glawo, which was the subject of the Ouagadougou seminar, a 'considerable warming' was expected in Africa as well as a 'remarkable' reduction in rainfall in sub-Saharan Africa and along the southern rim of the Mediterranean from now to 2050. These forecasts confirm those of the Intergovernmental Group of Experts on Climate Change, published in 2007. The Group's report forecast a 5\% to $8 \%$ extension of arid and semi-arid lands from now to 2080, an increase in 
the number of people suffering from lack of water from now to 2020, and worsening difficulties for agriculture that could halve agricultural production in some countries [17].

The elevation of sea level could also affect coastal countries such as Ghana, Nigeria, and Gambia; Stefan Cramer, of the Heinrich Boll Foundation, who attended the conference in Accra, underlined the impact that would be felt particularly in the deltas, where populations are dense. For instance, Lagos, Nigeria's economic capital, with 15 million inhabitants, would be seriously affected; several districts of the city that are situated below sea level are already regularly flooded. This overall situation is compounded by the increase in population growth and by the lack of resources. According to the United Nations Division of Population, the number of people living in Africa would rise from 922 million in 2005 to 1,998 million in 2050. While economic growth has been rather high over the past few years $(6.2 \%$ in 2007, according to the Economic Report on Africa by the United Nations and the African Union), public aid from the rich countries was slumping $(-8.4 \%$ in 2007 , according to the Organization for Economic Cooperation and Development (OECD); [17]).

The study published on June 3, 2011 by the Consultative Group on International Agricultural Research (CGIAR) and based on a comprehensive mapping work concluded that regions where food insecurity was highest were also those where climate change was expected to drastically change farming activities. These regions are mainly located in Africa and South Asia, but China and Latin America could also be affected. In less than 40 years, the agricultural seasons of these regions will be shorter, warmer and drier, jeopardizing the life of hundreds of millions of people who are already poor or very poor. Farmers have already made efforts to adjust to climate variations through modifying the sowing periods or changing grazing lands. But the CGIAR's study underlined that the rapidity and range of climate change would most probably need more drastic adaptations. Beyond average maximum temperatures above $30^{\circ} \mathrm{C}$, yields of rice and maize are affected, while the cultivation of beans becomes very difficult. Tens of millions of small farmers in sub-Saharan Africa might be confronted with such a situation by 2050 [18].

On the other hand, in a new study, the London-based charity Oxfam stated the international community is sleepwalking' towards a humanitarian catastrophe, as rising food prices threaten to cause a range of demographic and social crises. The report, Growing a Better Future, indicated that prices for basic staples might rise to $120 \%$ to $180 \%$ of their current levels by 2030 (Table 1), partly as a result of climate change but also because of poor distribution and unfettered speculation in commodity markets by big banks and hedge funds. The trend could be
Table 1 Estimated rise in the cost of basic staples by 2030

\begin{tabular}{lcc}
\hline Crop & Without climate change (\%) & With climate change (\%) \\
\hline Paddy rice & 72 & 107 \\
\hline Wheat & 53 & 82 \\
\hline Maize & 71 & 126 \\
\hline Processed rice & 34 & 48 \\
\hline
\end{tabular}

reversed, according to Oxfam, if governments improved regulation and focused on the plight of small farmers.

Can Africa cope with global climate change using the means existing under the Kyoto Protocol? It does not seem to be the case. "The total amount of the projects funded in Africa by the Global Environment Facility (GEF) over the past 17 years was US $\$ 378$ million, while the global amount was more than US \$2.4 billion, stated Yvo de Boer in Accra. Regarding the 'mechanism of clean development', which allows for the funding of technology projects aimed at decreasing the emissions of greenhouse-effect gases, it is spreading slowly on the continent. 'Only $2 \%$ of the relevant projects existed in Africa, compared with $45 \%$ in China, $16 \%$ in India, and $13 \%$ in Chile; an unacceptable situation, stated Ewah Otu Eleri, who leads the International Center for Energy, Environment and Development, based in Nigeria [17].

On August 26, 2008, at a GEF meeting held in Cotonou (Benin), the French minister of ecology, Jean-Louis Borloo, made a strong plea on behalf of the French presidency of the European Union for an alliance between Europe and Africa during the negotiations on climate change. Addressing his colleagues from 14 countries of Equatorial and West Africa, he expressed his hope that 'Europe that has the historic responsibility of global warming' would review new financial flows in order to control deforestation and to develop Africa's energy resources [17].

Such a statement of Europe's goodwill was echoed at a Carbon African Forum, held in Dakar onSeptember 3-5, 2008, and where several projects on the mechanism of clean development were to be negotiated. It should be underlined that one of the main issues of the negotiations that will lead to the follow-up to the Kyoto Protocol is the inclusion of forests and forested areas into the deal, because reducing or eliminating deforestation leads to the prevention of greenhouse-effect gas emissions. According to Brice Lalonde, the French ambassador for the negotiations on climate change, the inclusion of forests in these negotiations depends on the accuracy of measurement of their actual acreage and of their emissions. A consensus seems to be achievable, as satellite technologies and other methods are now available for measuring those emissions. A general agreement will now be necessary for the inclusion of forests in the carbon market, because one is dealing with a very important 
volume of greenhouse-effect gases that surpasses Europe's emissions. Regarding Africa, if a mechanism were designed to avoid deforestation, the countries of the Congo basin would benefit [17]. Another solution to deforestation carried out to clear out land for agriculture is to support agricultural intensification through the rational distribution of fertilizers; if yields of food crops are increased, farmers will not clear the forests to extend farmland acreage.

\section{Inadequate food supply: The key cause of food insecurity \\ Demand side}

The chronically tight food supply the world is facing is driven by the cumulative effect of several well-established trends that affect global demand and supply. On the demand side, the trends include the continuing addition of 70 million people per year to the Earth's population and the desire of some 4 billion people to move up the food chain and consume livestock products. In China, for instance, annual per capita consumption of meat has risen from $20 \mathrm{~kg}$ to $50 \mathrm{~kg}$ in less than 30 years. About half of the grains produced in the world are used to feed the livestock. That is why the increases in cereal and fodder prices have a strong impact on livestock products: milk rose $80 \%$ to $200 \%$, while poultry rose $10 \%[12,19]$.

Thus, after about 40 years of decrease in the global prices of cereals $(-60 \%)$, while production has been growing, 2 years were sufficient to send prices soaring. It was not therefore possible for several developing countries' governments to supply cheap food to their city dwellers. On the other hand, $80 \%$ of the 3 billion people surviving below the poverty threshold live in rural areas and have increasing difficulties in feeding themselves. The FAO listed over 30 countries for which the soaring price of food has been dramatic: in Africa, Burundi, Central African Republic, Chad, Côte d' Ivoire, Democratic Republic of Congo, Eritrea, Ethiopia, Ghana, Guinea-Bissau, Kenya, Lesotho, Liberia, Mauritania, Sierra Leone, Somalia, Sudan, Swaziland, Uganda, Zimbabwe; in Asia, Afghanistan, Bangladesh, Indonesia, Iraq, North Korea, Nepal, Pakistan, Sri Lanka and East Timor; in Latin America, Bolivia, Dominican Republic, Haiti, Nicaragua; in Europe, Moldavia and Chechnya (Russian Federation). Of these countries, one out of three is confronted with political problems, that is civil war and/or general insecurity $[20,21]$.

Still on the demand side, and without overestimating their impact, the use of maize to produce bioethanol in the United States has raised the annual global grain consumption [22].

\section{Supply side}

On the supply side, there is not much new land to be brought under the plough unless it comes from clearing tropical forests or from clearing the Brazilian cerrados (savannah-like regions south of the Amazon forest). This has heavy environmental costs, for example increased rainfall run-off and soil erosion. And in many countries, prime cropland is being lost to both industrial and residential construction and to the paving of land for roads, highways, and parking lots for fast-growing automobile fleets. Now, sources of irrigation water are even more scarce than new land to plough. During the latter half of the 20th century, the world's irrigated area nearly trebled, expanding from 94 million hectares in 1950 to 276 million hectares in 2000. Since then, the irrigated area per person has been shrinking by $1 \%$ a year [12].

It is therefore obvious that the global supply of food is insufficient. As stated by Jacques Chirac, the former president of France, 'I have never ceased to fight against the freezing of production in Europe and to promote agricultural development in poor countries...' 'Everybody at last realizes that humankind needs all its cropland. Food selfsufficiency is the first challenge developing countries should face and resolve' [23].

\section{Food security: how to achieve it?}

Food self-sufficiency advocated in the 1970s and supported by many countries was replaced in the 1990s by the concept of food security, the objective of which is to make available all foodstuffs in sufficient quantities and with the adequate nutritional qualities, whatever is their origin, be they produced locally, imported, or donated as food aid. That is why the promoters of free trade demand the opening of countries to imports of food, considering that consumers worldwide have the right to purchase their foodstuffs at the lowest cost possible. However, in a world market dominated by large agrifood companies and by the subsidized agricultures of Western countries, agricultural and food prices have been, since 1990, on a downward trend. This meant very harsh competition for small producers from developing countries, for whom it is increasingly difficult to live from their farm activities. Their production costs are higher than for imported food, whose dumping prices discourage them from producing more [24].

In addition, the food dependence of many developing countries has increased markedly. For instance, in West Africa, rice imports have multiplied eight-fold since 1960 and those of meat have trebled in 20 years. Hard currency provided by agricultural exports from West Africa just pays for food imports, $70 \%$ of which compete with local products. Consequently, networks and coalitions of producers have been created in order to advocate and defend their right to food sovereignty. Their claims are directed to the World Trade Organization (WTO) with a view to changing the rules of world trade, and also to encourage governments to adopt agricultural policies that support local producers. On its side, the FAO, through 
its Voluntary Directives developed in 2004, encouraged its member states to translate the right to food in concrete terms as the right for all to be able to feed themselves in a decent way [24].

The end of the era of cheap food has coincided with growing concern about the prospects of feeding the world. By October to November 2011, the global population rose to 7 billion, and the spike in food prices has once again plunged into poverty millions of people who spend more than half their income on food. The number of those below the poverty level of US $\$ 1.25$ per day, which had been falling consistently in the 1990s, rose sharply in 2007-2008. This suggested that the world could not even feed its current population, let alone the 9 billion expected by 2050. Adding further to these concerns is climate change, of which agriculture is both cause and victim [9].

The food crisis has produced a variety of proposed solutions. One group argues that high and volatile prices will make the task harder and that more needs to be done to boost supplies through the spread of modern farming, crop research, and food processing in poor countries. For the actors in this group (food companies, crop breeders, and international development agencies) the green revolution of the 1960s was a stunning success and needs to be followed by a second one [9].

The alternative view is sceptical of, or even downright hostile to, the modern food business. This group, influential among NGOs and some consumers' associations, focuses more on the food problems of wealthier countries, such as concerns about animal welfare and obesity. It argues that modern agriculture produces food that is tasteless, nutritionally inadequate, and environmentally disastrous. It considers that the green revolution has been a failure, or at least it has done more environmental damage and brought fewer benefits than anyone expected [9].

Feeding the world in 2050 will not be easy, and 'business as usual' will not achieve it. There are ways and means to boost yields of the main crops; despite the constraints of land and water, fertilizers and pesticides are available and although the concerns of the critics of modern agriculture may be understandable, the reaction against intensive farming is not always justified. Organic farming has a role to play and, indeed, its growth rate is important, but it cannot feed the world [9].

In 1996, the FAO estimated that the world was producing enough food to provide every woman, man, and child with 2,700 kcal each day, several hundred more than most adults are thought to need (around 2,300 kcal a day). The medical journal The Lancet reckoned that people needed no more than $90 \mathrm{~g}$ of meat a day. On average, they eat more than that, nowadays. Abhijit Banerjee of the Massachusetts Institute of Technology
Department of Economics, stated 'We live in a world that is capable of feeding every person that lives on the planet. If there is a food problem, it does not look like a technical or biological one.' Therefore, why worry about producing more food? Part of the answer is prices. If output falls below demand, prices will tend to rise, even if 'excess' calories are being produced. That happened in 2007-2008, and was occurring again in 2011. Over the period 2007-2010, prices were more volatile than they had been for decades. This situation is bad for farmers (who are left not knowing how and where to invest) and worse for consumers, especially the poor, who risk suddenly being unable to afford basic food [9].

Another part of the answer is that it is hard to improve distribution and reduce poverty. The world may indeed produce masses of calories, but the food is not always where it needs to be, and biofuel policy is hard to change. Pushing up supplies may be easier than solving the distribution problems. The overall task remains a daunting one. In order to keep up with population growth, farmers will have to grow more wheat and maize over the next 40 years than was grown in the previous 500. The balance between what is consumed and what farmers produce matters a great deal [9].

Regarding consumption, which can be forecast with some accuracy, the predictable rise in the world's population, from 7 billion by the end of 2011 to just over 9 billion in 2050, is the equivalent of two extra Indias. If we include the 1 billion people who are now starving, the additional mouths to feed over the next 40 years add up to three extra Indias. It does not seem an impossible task. The increase in world population by 2050 will be around $30 \%$, less than in the 40 years to 2010 , when it rose by over $80 \%$. Consumption of wheat, rice, and maize roughly tracks population growth, but at a higher level, so demand for them will add about a billion tons to the 2 billion produced in 2005-2007. That is much less than during the previous 40 years, when cereal production rose by $250 \%$ (The Economist, 2011).

In $2000,56 \%$ of all the calories consumed in developing countries were provided by cereals and $20 \%$ by meat, dairy products, and vegetable oils. By 2050, the FAO estimates that the contribution of cereals will have dropped to $46 \%$ and that of meat, dairy, and fats will have risen to $29 \%$. To match that soaring demand, meat production will need to increase to 470 million tons by 2050, almost double its current level. Output of soybeans (most of which are fed to livestock) will need to more than double, to 515 million tons [9].

Overall the FAO estimates that total demand for food will rise by about $70 \%$ in the 44 years from 2006 to 2050 , more than twice as much as demand for cereals. But that is still less than half as much as the rise in food production in the 44 years from 1962 to 2006 . So, according to 
the FAO, producing enough food to feed the world in the next four decades should be easier than in the previous four. However, increasing food supplies by $70 \%$ in the next 40 years may prove harder than it was to raise them by $150 \%$ in the previous 40 . The main reason is that the growth in yields has been slowing down, from about 3\% a year for staple crops in the 1960s to around $1 \%$ nowadays [9].

\section{Another green revolution}

\section{The challenges}

Agriculture must respond to the challenge of feeding 9 billion people, while protecting the environment and taking care of rural societies. It will be necessary to:

1. Eradicate hunger and ensure food security; global food needs will be three times higher in 2030 than they are nowadays. Some production factors can be increased, for example ploughing out more land (like the cerrados in Brazil), improving the access to scientific and technological progress (for instance, agrobiotechnology), more research and development.

2. Protect the environment and mitigate the impact of human activities on the environment. The threats are known: salinization of soils; increase in sea levels and catastrophic floods; desertification; loss of tropical forests and of the associated biological diversity; overexploitation of farmland and pastures; water scarcity; urbanization and large-scale engineering works.

3. Take care of rural societies. There are over 300,000 industrial megafarms and 1 billion family farms. The 4 billion human beings who make up the rural societies can alter, through their migrations, the demographic balance. The necessary increase in agricultural production must not ignore the implications for rural societies. A massive exodus from the countryside to the cities will cause enormous problems since cities, industries, and services cannot welcome rural people properly.

There must be a prospective approach to agricultural development:

1. The political process must strike an appropriate balance between peoples' right to food security and free trade without frontiers; the science and trade dynamics and the vulnerability of societies, as well as of the environment; the natural and cultural regional diversity and the trend towards the globalization of a model (after the globalization of exchanges).

2. Good practices must be identified and examples of successful agricultural development should be publicized. In other words, the agricultural models that will lead to sustainable development must be prioritized. The frequency and increased intensity of extreme climatic events, such as droughts and floods, have become additional challenges for global agriculture, which is already facing higher demand due to both population increase and new consumption habits of several developing countries. In order to respond to this challenge, the selection of drought-resistant crops is part of the solution. In December 2010, Bernard Bachelier of the Fondation pour l'agriculture et la ruralité dans le monde (FARM) published a study on the prospects of genetic improvement of crops tolerant to drought. But this is not easy: the control of genes coding for water stress and extreme temperatures is very difficult; it is much more complex to develop these kinds of plants than pesticide-resistant crop varieties. Research in this area is in its initial stages and it targets crops with high economic potential, such as maize, and to a lesser extent, rice, sorghum, or millet, which play a smaller role in global trade, but which are nevertheless essential for feeding the populations of several developing countries [2]. But improved seeds are just one element of crop systems. Farmers confronted with weather vagaries or climate change should be assisted in the improvement of irrigation systems that enable crops to improve their resistance to drought, according to Hafez Ghanem, assistant Director-General of the FAO. Only $4 \%$ of agricultural lands in Africa are irrigated [2].

3. Worldwide governance must highlight sustainable agricultural development via the WTO's negotiations on agriculture (Doha round), and the impact on developing countries of subsidies aimed at supporting exports of agricultural commodities.

\section{The African challenge}

Of the total of underfed people in the world, at least one-fourth live in Africa. This is the only continent where agricultural production per capita has been decreasing for the past 30 years; it is also the continent where agriculture suffered most from erroneous or inappropriate policies. Between 1970 and 1997, armed conflicts caused losses of agricultural production estimated at about US\$52 billion, that is the equivalent of $75 \%$ of the total public aid received during the same period.

Africa, where people under 15 years old represent some $45 \%$ of the whole population, will have to feed a population that is expected to increase from 832 million in 2002 to more than 1.8 billion by 2050 . The agricultural sector, which employs about $60 \%$ of the whole population, represents some $20 \%$ of the gross domestic product (GDP) and provides more than $10 \%$ of the export revenues. It should become the driving force of 
economic and social development. In July 2003, at their summit in Maputo, Mozambique, the heads of the states and governments of the African Union made a commitment to double the part of their domestic budgets devoted to agriculture by $2010-2011$, so as to reach $10 \%$.

By early September 2011, in Montpellier, south-east France, during the Conference on Agricultural Research for Development of the G20 (attended by the member countries of the G20, international organizations and French research bodies, including the Research for Development Institute (IRD)), Monty Jones, president of the World Agricultural Research Forum, executive director of the Africa Agricultural Research Forum, and World Food Prize 2004 Laureate, stated: 'Nowadays, 20\% of Africa's population is underfed or malnourished and its population growth rate is the fastest in the world, 1.8 billion or even 2 billion people in 2050. It is therefore crucial that food production must increase: agricultural strategies should be changed as in the emerging countries, and Africa must adopt a range of strategies. In addition, the necessary infrastructures must be built in order to fit the expected growth in production. Finally, we need to build a domestic market, which was up to now small and fragmented, making it more regional and linking it better with the international markets'. M. Jones gave the example of Rwanda, which made the right decisions after the civil war and is now among the most advanced African countries in agriculture, having increased both its production and productivity, and improved the quality of life of its population. In Sciences au Sud (pp. 1 and 5) [25], M. Jones added that Africa's green revolution cannot be the same as that of Asia. There is not in Africa a unique solution such as the one based on rice because African staple foods are different, and technologies should be adapted to a distinct context.

Whereas the yield of irrigated agriculture is three times higher than that of rainfed agriculture, Africa only uses $4 \%$ of its available water resources for irrigation; only $7 \%$ of farmland (1.6\% in sub-Saharan Africa) is irrigated. By contrast, $40 \%$ of farmland is irrigated in Asia. The recommended objective is to irrigate $14 \%$ of farmland.

An FAO special programme for food security is being implemented in 101 countries, including 42 in Africa. On November 1, 2004, US\$766 million had been collected, $67 \%$ of which was provided by domestic budgets in the developing countries. The aims are to increase the harvests of cereal, horticultural, and fruit crops through the introduction of higher-yielding varieties; to develop livestock husbandry (small animals and poultry), fisheries and aquaculture; to control insect pests and parasites of plants and animals (for example planting $B t$ cotton in South Africa and Burkina Faso); to improve food-safety standards so as to facilitate the access of produce to international markets; and to strengthen infrastructures that are needed for marketing products at competitive prices.

Africa has a number of assets. It has plenty of natural resources. The internal market should reach 2 billion people, while for the producers of goods and services, there are great advantages to draw from converting 250 million underfed persons into consumers with an effective purchasing power. According to an FAO study carried out between 1960 and 1990 in 110 countries, the annual GDP per capita in sub-Saharan Africa could have reached between US\$1,000 and US\$3,500 in 1990 if no malnutrition had occurred; in fact, it did not exceed US\$800.

The spike in food and oil prices (due in particular to the popular uprisings in North Africa and the Middle East) has led the World Bank and its subsidiary, International Finance Corporation (IFC), to strengthen their policy of giving a top priority to sub-Saharan Africa regarding their investments into agrifood projects. Financial commitments of the IFC in this region have risen over 8 years from US\$140 million ( $€ 100$ million) in seven countries up to US\$2.4 million in 33 countries. This amount, which included loans and participation shares, represented $19 \%$ of the investments made by the IFC to support development worldwide, via enterprises, and not via governments. Thus, the IFC has funded and advised societies which linked 13.5 million new consumers to the electricity grid and 47 million people to a mobile-phone company, and which created 161,000 jobs in 2010 [26].

Agrifood projects are a top priority for IFC. Thierry Tanoh, the IFC's vice-president since 2003, stated in this respect: 'Why would Burkina Faso, which exports its herds on hoof and loses during the journey one-fourth of the meat weight, not instead create in Ouagadougou a slaughterhouse with the required norms so as to export packaged meat in trucks?' It is true that the cold chain is not guaranteed because of the lack of electricity, a real plague throughout the continent. The latter needs about 7,000 megaWatts (MW) more every year, while only 1,000 MW are installed. The IFC is therefore supporting studies for building dams and hydroelectric plants. In 2014, about US $\$ 3$ billion are expected to be invested in sub-Saharan Africa by the IFC, and mostly in agrifood projects that will consist of producing more staple foods and transferring them locally. This approach will not only improve the food situation, but also make foodstuffs processed in Africa more competitive regionally and globally [26].

\section{Africa wants to make its green revolution}

By the late 1960s, under the auspices of the World Bank (which at that time increased by $80 \%$ the funds devoted to agriculture for 2 years), the green revolution had been a success in Asia and Latin America. But it failed in 
Africa. Climate vagaries and credit crunch, soil fertility and insufficient use of fertilizer, and above all, the weakness of the governments, made public administrations and their tools (such as credit organisms, stabilization bodies, training institutions, and dissemination of technologies) inefficient and often corrupted. They also were the first victims of policies of structural adjustment, carried out since the 1980s to save African states from bankruptcy [27].

The result was that, since the 1990s, agricultural and food production in sub-Saharan Africa has grown much less than that in other regions of the developing world. Between 1996 and 2005, food production rose 2.6\% (compared with $3.3 \%$ in all developing countries). Of all farmland, $3.5 \%$ was irrigated (compared with $22.4 \%$ in the rest of the developing world), and fertilizer use amounted to $13.4 \mathrm{~kg}$ per hectare (compared with $115.2 \mathrm{~kg}$ per hectare). The balance of food in African countries had a deficit of more than US $\$ 900$ million in 2004, while it was in excess in Brazil by US $\$ 15.5$ billion, in Argentina by about US $\$ 10$ billion, in France by US $\$ 5.7$ billion, and in India by almost US $\$ 4$ billion [27].

According to the FAO's estimates, the number of kcal consumed per day and per capita reached an average of 2,260 in 2001-2003, that is a $0.37 \%$ increase over 10 years. For all developing countries, these figures were 2,660 and $0.49 \%$, respectively, and 2,670 and $0.56 \%$ for the Asia Pacific region. In 2004, 64\% of the African population was living in rural areas and 59\% made a thin living from agriculture; $45 \%$ of this rural population had access to a source of drinking water and $6.1 \%$ to electricity [27].

The failure was obvious and since 1994, Ismail Serageldin, vice president of the World Bank, has set up a working group on agriculture foresight. This group, led by the ecologist Gordon Conway, proposed a vision for a more environmentally-friendly agriculture. This proposal was included in the Millennium Ecosystem Assessment (MEA), launched by the United Nations and involving 1,300 scientists between 2001 and 2005, and coordinated by the CGIAR. In 2005, the International Assessment of Agricultural Science and Technology for Development (IAASTD) followed suit; 800 researchers have been involved under the aegis of the United Nations and the World Bank; their work ended in 2007 [27].

Regarding Africa, at the African Green Revolution Forum, held in Accra, Ghana, at the beginning of September 2010, and where several hundreds of ministers, entrepreneurs, representatives of agricultural organizations and international bodies, bankers, and experts were present, it was stated that there was a renewed interest in agriculture. 'Since 2000, there has been more awareness of the need to support agriculture', stated Mamadou Cissokho, honorary president of the Network of Farmers' and Agricultural Producers' Organizations of West Africa (Roppa). 'However, Africa has to recover from 25 years of structural adjustment policies and six severe droughts' [28].

In fact, in 2003, in Maputo, Mozambique, African heads of state made the commitment to devote $10 \%$ of their national budgets to agriculture. This aspect of funding agriculture is crucial, according to Monty Jones: 'When our governments do not increase funds allocated to agriculture, it implies that the support comes from external donors. But the latter cannot provide their support over more than three or four years. Consequently, a decrease in their assistance results in a significant reduction in production. That is the case for Malawi and Niger, he explained. He went on to comment that, in his view, famine in several parts of Africa (especially in the Horn of Africa) is due above all to persistent neglect of the agricultural sector by governments. In Somalia and neighbouring regions severely affected by famine, statistics on agricultural development and investments are among the worst in Africa, for example only $1 \%$ of arable land is irrigated, compared with $7 \%$ for the whole continent [25].

In 2006, the Alliance for a Green Revolution in Africa (AGRA) had been created and its council is chaired by Kofi Annan, the former United Nations Secretary-General. In 2008, 59 governments published a report written by 800 agronomists and other researchers: the IAASTD aimed at promoting an agronomy based on ecological processes as well as the support for food crops. But what kind of agricultural policy should be effectively carried out? Some NGOs consider that AGRA is supporting a technological solution, for example through the use of genetically-modified (GM) crops, which is promoted by the Rockefeller Foundation and the Bill and Melinda Gates Foundation (the latter has invested $€ 23$ million into Monsanto's research on GM crops). AGRA's president, Namanga Ngongi, reacted by stating: 'We are working with conventional seeds, but these need to be improved. Also, the use of fertilizer is crucial: Africa uses, on average, $8 \mathrm{~kg}$ of fertilizer per hectare, which is very little; if this amount could be increased to $30 \mathrm{~kg}$, this would change the face of agriculture' [28].

Kofi Annan, interviewed by the French newspaper Le Monde, also stated that improved seeds should be supplied to farmers, that agroproducts should be transformed and brought to market, or be stored for long periods. The aim is to enable farmers to meet their own needs and to sell their surplus on the market. Kofi Annan quoted the example of Mali, where researchers have developed a sorghum variety with a yield of 4 tons per hectare instead of the average of 1 ton per hectare. The government is fully committed to transforming the country's agriculture. A network of 150 stores supply 
seeds, fertilizers, and tools, and this saves the farmers travelling over long distances to buy the agricultural inputs they need. Kofi Annan considered that this combination of research, political will and good organization of the market should be extended, along with irrigation $[28,29]$.

Namanga Ngongi, AGRA's president, has underlined that technological improvement was not the only factor in improving African agriculture; '... it is also necessary to reduce the costs of transactions, to better manage training and commercialization, to mobilize local banks; capital is not lacking, but rather experience and methods to lend money to the small farmer'. Many agronomists consider that a green revolution in Africa cannot be based on just technological improvements. Jacques Berthelot of the association Solidarité commented that 'The agricultural future of sub-Saharan Africa should be based on systems of agroecological production and agroforestry that do not need too many inputs.' 'During Agro 2010, the big international congress of the European Society of Agronomy, almost all presentations were dealing with agroecology,' confirmed Michel Griffon, deputy director of the French National Research Agency. Agroecology means the reliance on biological processes, the association of crops, trees, and livestock husbandry in agroforestry, the use of crop diversity in order to ensure better protection against pests and the development of organic fertilizers rather than chemical ones. In other words, agroecology does not just rely on the improvement of seeds and the use of fertilizers and pesticides [28].

This new approach to agricultural development has been supported by the CGIAR, which, for instance, highlighted the experience of the 'African vegetable garden', developed in Benin and Niger. It combines drip irrigation, vegetable crops, fruit trees, and the communitary sharing of costs [28].

Kofi Annan insisted on a key factor: political will. As an example, he indicated that in 2010, 11 African governments were investing $10 \%$ or more of their national budgets into agriculture. He considered that this commitment was going to be made by an ever-increasing number of countries, who realize that it is not just about meeting food-security needs, but also to create jobs and slow down rural exodus. The change in policy of the World Bank could help the movement [28].

As an illustration of the top priority that should be given to agricultural development and food security, it is worth mentioning the appeal made in November 2010 by Denis Sassou N' Guesso, president of the Republic of Congo-Brazzaville. In a country where oil contributes $90 \%$ of export revenues, agricultural activities have been neglected, while privileging a poorly diversified economy. Consequently, the Republic of Congo spent about 130 billion CFA francs (about $€ 20$ million) in 2010, that is the equivalent of all the salaries or wages paid by the state, to import the food and commodities needed to feed 4 million inhabitants [30].

This looks paradoxical because the country receives an abundant and regular rainfall, and has about 12 million hectares of arable land of which only $2 \%$ are exploited. Further to the appeal made by the Republic's president to 'win the battle for food self-sufficiency', the minister of agriculture and livestock husbandry stressed that the mindset should be changed while becoming aware of the wealth represented by agriculture. The latter should remain the top priority, had said the president [30]. The country's strategy is to support producers' organizations, to enable landlocked production areas to have an easier access to markets, to organize commercialization networks and to set up infrastructures for transforming agricultural production, storing and conserving agrifood products. Such a policy aims to achieve three objectives: increase the volume of agricultural exports, improve food security and create new jobs, and income for rural populations. According to decision-makers, the development of the agricultural sector is compounded by archaic production structures and the lack of storage facilities and transport of agrifood products to consumption markets. In fact, food crops are cultivated by small farmers using obsolete techniques with low yields in periurban areas that are rapidly shrinking because of extensive urbanization [30].

In order to obtain the expected results, the state has set up, with the help of funding institutions like the World Bank, a range of incentive programmes such as the National Food Security Programme (PNSA). The latter, with a fund of $€ 29$ million, is being carried out in partnership with the FAO, and aims at intensifying the production of food crops in each village with the assistance of Vietnamese and Chinese technicians, rehabilitating rural roads, setting up commercialization and inputdistribution bodies. Another development tool is the Project for Agricultural Development and Rehabilitation of Rural Roads (PDARR), which has received $€ 14.5$ million and intends to enable poor rural populations to draw more substantial income from their production through the supply of technological tools, the purchase of equipment and inputs at lower prices, and the building of market infrastructures [30].

The most emblematic development project is that of agricultural villages, the concept of which is inspired from that of the Israeli kibbutz. This programme has been launched by President Sassou N' Guesso and it received $€ 20$ million. The programme is expected to significantly increase agropastoral production, for example 8 million eggs and 6 million cassava cuttings per year. Each village located in a region having competitive 
agroecological conditions will welcome 50 families. Every one of these families will have a house and a 2-hectare area of farmland. Collective infrastructures have also been planned: a library, a recreation area, a medical center, an electricity grid, a drinking-water supply system, and roads. 'The development of agricultural villages in Congo will shed a positive light on agriculture and is expected to reshape Congolese rural societies during the third millennium. The exploitation of the immense agricultural potential of the country is made possible by a state policy based on agricultural mechanization and the creation of a Fund for Supporting Agriculture (FSA), commented the minister of agriculture and livestock husbandry [30].

This Fund was created in 2008 by the state and it aims to support agropastoral production and fisheries, and to assist the commercialization, storage, and transformation of all relevant products. The programme supported by the Fund consists of strengthening the institutional framework, carrying out research for the development of the relevant sectors, as well as extension activities in order to disseminate agricultural technologies and to train technicians. One of the Fund's priorities is to allocate more money to short-cycle crops such as vegetables, maize, and rice, as well as to poultry and swine husbandry. One of the successes of the Fund, with a budget of $€ 6.7$ million in 2011 (thus allowing the support of hundreds of projects), has been to involve banks that facilitate loans to farmers, especially to those who wanted to buy heavy equipment [30].

This strategy has drawn the attention of international agricultural companies that are settling in the Republic of Congo. Thus Congo Avenir, a partner of the South African AgriSA, acquired 80,000 hectares of farmland on 10 March 2011 further to an agreement signed with the Congolese government. This area will be devoted to larger-scale agropastoral activities. On the other hand, the Malaysian company Atama will develop oil-palm cultivation on 180,000 hectares with a view to producing 900,000 tons of palm-oil per year [30].

\section{Fair trade and competition}

But solving the problem of African agriculture does not depend on just technology and organization. According to Mamadou Cissokho, 'The agreements of the World Trade Organization have resulted in the elimination of tariff protection at the frontiers; African countries import up to $40 \%$ of their food, and they have neither a regional nor continental market. In order to be able to develop research and to build up regional markets, locally grown food crops need protection at the countries' borders.' This viewpoint is a major divergence with those who make a strong plea for the liberalization of trade. In addition, in Europe and the United States, farmers receive subsidies from their respective governments. In Africa, this should also be the case to help farmers overcome their difficulties and later become more competitive on regional and international markets [28].

As Western countries are reluctant to dismantle their trade barriers that protect their farmers against global competition, which led to the interruption in July 2006 of the WTO's negotiations on liberalization of trade, African states want to set up or strengthen barriers to enter their own agricultural markets. Thus, since January 1, 2006, 15 countries that are part of the Economic Community of West African States (CEDEAO) have imposed a common external tariff of $5 \%$ to $20 \%$ on imports, the highest tariffs concerned food products, thus restoring a mechanism adopted in 2000 by the French-speaking countries of the region. However, this tariff remained very low because the CEDEAO member states made the commitment to open up their markets within the framework of negotiations with their creditors, the World Bank, and the International Monetary Fund, on the alleviation of their debt. 'These countries, probably the weakest in the world, are also the most open: tariffs of $50 \%$ to $80 \%$ are imposed elsewhere, deplored Henri Rouillé d'Orfeuil, president of the NGO network, Coordination Sud. But here and there, some countries have taken more drastic measures in order to defend their production, such as Kenya in the case of milk, with positive results for local production and commercialization [31].

Such initiatives are contrary to free trade promoted by the WTO, which aims to help African countries to export on world markets. But 'the real access to the markets we seek for, is the access to our own national and regional markets', stated Ndiogou Fall, president of Roppa, in December 2006. On these markets, locally produced commodities are confronted with the competition of low-cost imported products, for example rice produced in Senegal against Thai rice, or poultry against frozen chicken meat. African agriculture cannot compete with such imported products due to a number of handicaps, like weather vagaries, soil degradation, ineffective road networks, lack of a cold chain, and lack of access to information on markets. Many economists have concluded, therefore, that African agriculture needs some tariff protection in order to be able to develop and become gradually competitive. There is also a need to set up national or regional agricultural policies that entail the necessary investments, just as was done in the European Union [31].

Thus, within the framework of its unified agricultural policy, in March 2006, the West African economic and monetary union (UEMOA) created a regional agriculture development fund with a view to promoting and developing commodity chains from production to commercialization 
for rice, maize, poultry meat, and so on. Similarly, the African Union and the New Partnership for Africa's Development (NEPAD) had launched in 2003 a programme of agriculture development that needed investments of about US\$251 billion, while public aid to development accounted to less than US\$1 billion in 2004. The African Union, in December 2006, expressed its concerns regarding the slow progress in the implementation of the commitment made in 2003 by each member of the Union to devote at least $10 \%$ of its national budget to agriculture and rural development over 5 years [31].

In a wider framework, the countries of the region Africa-Carribbean-Pacific (ACP) had to negotiate a new trade agreement with the European Union, which wanted to revise the trade preferences granted to the ACP countries in order to align them with the rules of the WTO. This had to be achieved by the beginning of 2008. The 77 ACP countries, three-quarters of which are African countries, were concerned that such revision may change the rules of the game affording them the advantages indicated in the Lome and Cotonou agreements and concerning the export of their agricultural products: bananas, sugar, or cotton. Europeans stated that they were willing to maintain some preferential tariffs if they had an equivalent access to the ACP countries' markets; in this case, the exports were mainly industrial goods and services. The revision of the agreements was necessary because the preferential tariffs granted exceptionally by the WTO were to expire in 2008; beyond this date, it would be illegal to maintain them, and they could be the target of an attack by competitors of ACP countries, such as Latin American ones. They had already done so regarding bananas: a number of Latin American countries are big producers and exporters of bananas; a tariff is imposed on the fruits imported by the European Union countries, whereas this is not the case for bananas imported from Africa or the French Antilles [32].

\section{Protection of African farmers}

An African green revolution cannot do away with the economic and political aspects mentioned above. Subsidizing African farmers and protecting them from the dumping of imported low-cost food and agricultural products are considered of crucial importance by many economists and NGOs. Thus, Bernard Njonga, in 2003, created the Citizen Association for the Defence of Collective Interests (ACDIC, Association Citoyenne de Défense des Intérêts Collectifs) in order to struggle against the imports of chickens and poultry meat. In an interview with the French newspaper Le Monde, he stated: 'Our domestic markets, after having been flooded by European products, are now flooded by those coming from South-East Asia and Latin America. In Cameroon, for instance, rice, tomatoes, onions, and maize are imported, while they can be grown locally. All local production structures have been progressively abandoned. Farmers, who represent $60 \%$ of active population, are weakened, unemployment rises, and young people migrate to the cities; it is the reverse of development.' In 2004, he launched with ACDIC a 'war' against the imports of frozen chicken from Europe. These imports were threatening Cameroon's producers and were jeopardizing the national economy, as well as the health of populations. The role of ACDIC is to support and advise the organizations of producers, in order to design their production strategies. ACDIC also helps define a national agricultural policy. In 2006, ACDIC launched a campaign on food sovereignty and collected the written support of citizens for subsidies to farmers. Not only did the producers follow the NGO, but consumers did too. It was thanks to the participation of the consumers in the battle against imported frozen chicken that the latter was won [33].

Another example of assistance to the farmers as a key to agricultural development and overall economic growth is that of Mozambique. Despite an annual GDP growth of between $8 \%$ and $13 \%$ over 10 years (except in 2000 because of catastrophic floods), Mozambique remains one of the poorest countries of the world, with $54 \%$ of its population, mainly rural, living on less than US\$1 per day. President Guebuza, elected in 2004, as well as the main donors of aid, was convinced that after 20 years of structural adjustment and opening to foreign industrial investments, priority had to be given to activities and job creation in the rural environment. Access to land should remain easy for farmers, but they must also have access to local markets thanks to good roads and to loans, as well as to training and technologies that will raise production. They ought to be protected against climate risks. There were some experts who made a strong plea in favour of land privatization because this will attract investments from agroindustrial groups. Others consider that such privatization would benefit only the social and economic leadership, who could purchase the land; banks would not like to have lands as a guarantee and become landlords in case the owner went bankrupt. Therefore the risk of having idle lands would become real. They consider that, instead of privatizing land, farmers' work should be organized and facilitated through all kinds of assistance, as mentioned above [27].

\section{Abbreviations}

ACDIC: Association Citoyenne de Défense des Intérêts Collectifs; ACP: Africa-Carribbean-Pacific; AGRA: Alliance for a Green Revolution in Africa; CEDEAO: Economic Community of West African States; CGIAR: Consultative Group on International Agricultural Research; FAO: Food and Agriculture Organization of the United Nations; FARM: Fondation pour l'agriculture et la ruralité dans le monde; FSA: Fund for Supporting Agriculture; GDP: Gross domestic product; GEF: Global Environment Facility; GM:

Genetically-modified; IAASTD: International Assessment of Agricultural 
Science and Technology for Development; IFC: International Finance Corporation; IRD: Research for Development Institute; KARI: Kenya Agricultural Research Institute; MDG: Millennium development goal; MEA: Millennium Ecosystem Assessment; NEPAD: New Partnership for Africa's Development; NGO: Non-governmental organization; OECD: Organization for Economic Cooperation and Development; PDARR: Project for Agricultural Development and Rehabilitation of Rural Roads; PNSA: National Food Security Programme; Roppa: Network of Farmers' and Agricultural Producers' Organizations of West Africa; UEMOA: West African Economic and Monetary Union; UNICEF: United Nations Children's Fund; WFP: World Food Programme; WTO: World Trade Organization.

\section{Acknowledgements}

I thank Jessica Mnatzaganian for her superb work preparing this manuscript.

Received: 5 January 2012 Accepted: 1 March 2012

Published: 19 April 2012

\section{References}

1. Van Eeckhout L: En 2010, la faim a un peu reculé dans le monde. Le Monde 2010, 1:4

2. Van Eeckhout L: Alerte sur un risque de crise alimentaire. Le Monde 2011, February 6-7:4

3. Sasson A: The global food crisis. Causes, prospects, solutions. Rabat, Morocco: Hassan II Academy of Science and Technology; 2009.

4. Cypel S: La sécurité alimentaire, l'autre chantier de Bill Gates. Le Monde 2010, April 24:4.

5. Hervieu S, Van Eeckhout L: Le sud de Madagascar est menacé par la famine. Le Monde 2010, December 16:4.

6. Hervieu S: Au Kenya, la sécheresse décime les troupeaux. Le Monde 2011 July 12:8.

7. Hervieu S: Au Kenya, les fermiers abandonnent le maïs pour le manioc. Le Monde 2011, July 21:9.

8. Degbe E: Les filles moins bien loties en cas de crise alimentaire. Santé, education, violences: les adolescentes perdent sur tous les tableaux. Le Monde 2011, February 26:8.

9. A special report on feeding the world. The 9 billion-people question. The Economist 2011, February 26:1.

10. Lacey M: High food prices incite rising anger. Le Monde/New York Times 2008, April 26:1-4.

11. Walt V: A furious hunger. Time 2008, 17:42-43.

12. Brown LR: World facing huge new challenge on food front. Business as usual not a viable option. Earth Policy Institute, Plan B Update, 16 April 2008. [http://www.earth-policy.org/plan_b_updates/2008/update72]

13. Tuquoi J-P: Au Maroc, I'augmentation du prix du pain provoque des manifestations. Le Monde 2007, October 17:22.

14. Riots in Mozambique. The angry poor. The Economist 2010, September 11:38.

15. Rémy J-P: Des hausses de prix déclenchent des émeutes sanglantes au Mozambique. Le Monde 2010, September 4:6.

16. Lemaître F: Une crise alimentaire majeure se profile. Le Monde 2008, February 9:2.

17. Kempf H: L'Afrique, "continent oublié" de la négociation climatique. Le Monde 2008, August 28:8

18. Caramel $L$ : La sécheresse en Europe menace l'approvisionnement en céréales des pays pauvres. Le Monde 2011, June 4:8.

19. Spore (The Technical Centre for Agricultural and Rural Cooperation, CTA ACP-EU, Wageningen, The Netherlands), no. 134, April 2008, p. 2.

20. Tuquoi J-P, Caramel L, Clavreul L, Kempf H: La production agricole augmente, mais moins vite que la demande. Le Monde 2008, April 13-14:4.

21. Méhaignerie P et al: Que faire contre la faim? Le Monde 2008, May 2:20.

22. Sasson A: Bioenergy and agrofuels. Relevance beyond polemics. Rabat, Morocco: Hassan II Academy of Science and Technology; 2008.

23. Chirac J: Crise alimentaire: des solutions existent. Le Monde 2008, April 17:22.

24. Spore (The Technical Centre for Agricultural and Rural Cooperation, CTA, ACP-EU, Wageningen, The Netherlands), no. 128, April 2007, pp. 1-2

25. Sciences au Sud (French Research for Development Institute, IRD, Journal), no. 61, September-October 2011.
26. Faujas A: La Banque mondiale investit dans l'agroalimentaire en Afrique subsaharienne pour contenir la hausse des prix. Le Monde 2011 March 5:14.

27. Reverchon A: Replacer les agriculteurs au centre du développement. Le Monde Economie 2007, January 16:II-II.

28. Kempf H: L'agriculture africaine veut faire sa révolution verte. $\mathrm{M}$. Annan "il ne s'agit pas seulement d'assurer la sécurité alimentaire, mais d'exporter". Le Monde 2010, September 4:4.

29. Sasson A: Agricultural biotechnology applications in Africa. In Agriculture, human security and peace. Edited by Taieb M, Zakri AH. West Lafayette, IN: Purdue University Press; 2008:157-187.

30. Bambou F: Développement durable. L'or vert. Biocarburants, bioenergie... Sur le chemin du green business. Agriculture, une bataille vitale. Afrique Magazine Am 2011, 314:89-98.

31. Tricornot A de: Des Etats sans véritable stratégie. Le Monde Economie 2007, January $16: 1$.

32. Ricard P: 2008, les risques du libre-échange. Le Monde Economie 2007, January 16:I

33. Clavreul L: Bernard Njonga: "il faut des subventions pour que les paysans investissent". Le Monde Economie 2007, January 16:Il.

doi:10.1186/2048-7010-1-2

Cite this article as: Sasson: Food security for Africa: an urgent global challenge. Agriculture \& Food Security 2012 1:2.

\section{Submit your next manuscript to BioMed Central and take full advantage of:}

- Convenient online submission

- Thorough peer review

- No space constraints or color figure charges

- Immediate publication on acceptance

- Inclusion in PubMed, CAS, Scopus and Google Scholar

- Research which is freely available for redistribution 